\title{
Reactive oxidation products promote secondary organic aerosol formation from green leaf volatiles
}

\author{
J. F. Hamilton ${ }^{1}$, A. C. Lewis ${ }^{1}$, T. J. Carey ${ }^{2}$, J. C. Wenger ${ }^{2}$, E. Borrás i Garcia ${ }^{3}$, and A. Muñoz ${ }^{3}$ \\ ${ }^{1}$ Department of Chemistry, University of York, Heslington, York, YO10 5DD, UK \\ ${ }^{2}$ Department of Chemistry and Environmental Research Institute, University College Cork, Cork, Ireland \\ ${ }^{3}$ Fundación Centro de Estudios Ambientales del Mediterráneo (CEAM), EUPHORE laboratories, C/Charles Darwin, \\ 14-Parque Tecnológico, Paterna, Valencia, Spain
}

Received: 24 November 2008 - Published in Atmos. Chem. Phys. Discuss.: 5 February 2009

Revised: 20 May 2009 - Accepted: 21 May 2009 - Published: 12 June 2009

\begin{abstract}
Green leaf volatiles (GLVs) are an important group of chemicals released by vegetation which have emission fluxes that can be significantly increased when plants are damaged or stressed. A series of simulation chamber experiments has been conducted at the European Photoreactor in Valencia, Spain, to investigate secondary organic aerosol (SOA) formation from the atmospheric oxidation of the major GLVs cis-3-hexenylacetate and cis-3-hexen-1-ol. Liquid chromatography-ion trap mass spectrometry was used to identify chemical species present in the SOA. Cis-3-hexen1 -ol proved to be a more efficient SOA precursor due to the high reactivity of its first generation oxidation product, 3-hydroxypropanal, which can hydrate and undergo further reactions with other aldehydes resulting in SOA dominated by higher molecular weight oligomers. The lower SOA yields produced from cis-3-hexenylacetate are attributed to the acetate functionality, which inhibits oligomer formation in the particle phase. Based on observed SOA yields and best estimates of global emissions, these compounds may be calculated to be a substantial unidentified global source of SOA, contributing $1-5 \mathrm{TgC}^{-1}$, equivalent to around a third of that predicted from isoprene. Molecular characterization of the SOA, combined with organic mechanistic information, has provided evidence that the formation of organic aerosols from GLVs is closely related to the reactivity of their first generation atmospheric oxidation products, and indicates that this may be a simple parameter that could be used in assessing the aerosol formation potential for other unstudied organic compounds in the atmosphere.
\end{abstract}

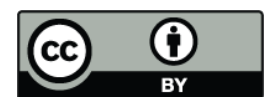

Correspondence to: J. F. Hamilton (jfh2@york.ac.uk)

\section{Introduction}

Atmospheric aerosols play a central role in climate, air quality and transboundary air pollution (Kanakidou et al., 2005). However, there are significant uncertainties in the environmental impact of aerosols owing to limited knowledge on their sources, composition, properties, and the mechanisms of their formation (Fuzzi et al.,2006). The oxidation of biogenic compounds in the atmosphere can result in the formation of lower volatility species which can form biogenic secondary organic aerosol (BSOA), one of the most uncertain factors in the global radiation budget (Intergovermental Panel for Climate Change, 2007). Vegetation can be classified according to the type of biogenic volatile organic compounds (BVOC) emitted - typically bulked as either isoprene, monoterpene or oxygenated VOC emitters (Penuelas and Llusia, 2001). There is a substantial historical literature on BVOC emissions which has focused almost exclusively on isoprene and monoterpenes, driven in part by ease of field observation (Guenther et al., 1995; Ortega and Helmig, 2008). Calculations of the impacts of BVOCs on the atmospheric aerosol burden have followed the literature generated by emission studies, resulting in a major focus on the SOA-forming potential of isoprene and a small subset of monoterpenes (Claeys et al., 2004; Henze and Seinfeld, 2006; Hoffmann and Warnke, 2007; Larsen et al., 2001; Lee et al., 2006). As analytical techniques have improved however, more recent work indicates that sesquiterpenes and reactive oxidised organic compounds may also be emitted in substantial quantities and act as effective BSOA precursors (Bonn and Moortgat, 2003; Fuentes et al., 2000; Holzinger et al., 2005; Kesselmeier and Staudt, 1999; Konig et al., 1995). Guenther et al. (1995) estimated the global BVOC budget based on a highly resolved global model and emissions from plant foliage on the basis of ecosystem type and emission factors. The annual global flux of BVOC was estimated to

Published by Copernicus Publications on behalf of the European Geosciences Union. 
be $1150 \mathrm{TgC}^{-1}$, comprising $44 \%$ isoprene, $11 \%$ monoterpenes, $22.5 \%$ other reactive VOC and $22.5 \%$ other nonreactive VOC. Viewed purely in mass emission terms the non-isoprene and non-monoterpene reactive biogenic VOC emissions cannot be treated as insignificant. A recent estimate of global SOA production, based on VOC fluxes, indicated that there may be considerable numbers of significant SOA precursors that are currently unknown (Goldstein and Galbally, 2007).

One of the most significant groups of BVOC are green leaf volatiles (GLVs), a family of oxygenated hydrocarbons produced from the biochemical conversion of linoleic and linolenic acid within plant cells, as shown in Fig. 1. Recent studies have indicated that many plant types emit large quantities of GLVs (Arey et al., 1991; Konig et al., 1995; Winer et al., 1992), with cis-3-hexenylacetate and cis-3-hexen-1-ol being the dominant species emitted from wheat, oilseed rape, grape and birch trees. The emission of GLVs from plants can be significantly enhanced by mechanical damage of leaves caused by grass cutting, grazing of animals etc. (Kirstine and Galbally, 2004; Olofsson et al., 2003). Local weather conditions can also result in the release of GLVs; high concentrations of GLVs (up to 5 ppbv) were seen in the Alps after a freezing spell, and were attributed to emission from damaged cells upon thawing (Karl et al., 2001). The recent study of Joutsensaari et al. (2005) indicated that these types of stress induced emissions from plants can form increased levels of SOA over healthy plants and are likely to be important aerosol precursors. Previous studies of the atmospheric chemistry of cis-3-hexenylacetate and cis-3-hexen-1-ol, indicate that they are highly reactive towards hydroxyl radicals and ozone (Atkinson et al., 1995) and have short tropospheric lifetimes, of the order of a few hours (Atkinson and Arey, 2003; Olofsson et al., 2003).

In this study, we have investigated secondary organic aerosol formation from the ozonolysis and photooxidation of 2 major GLV compounds, cis-3-hexen-1-ol and cis-3hexenylacetate, in a series of experiments performed in an atmospheric simulation chamber. The chemical composition of the SOA formed from ozonolysis was investigated using liquid chromatography coupled to ion-trap mass spectrometry and the structures of oligomeric species identified using fragmentation patterns. The SOA yields obtained from the photooxidation of cis-3-hexen-1-ol and cis-3-hexenylacetate are compared to those obtained from isoprene and the results used, in conjunction with estimated emission fluxes, to assess the potential importance of GLVs as a global source of SOA.

\section{Experimental}

The experiments were carried out in the large atmospheric simulation chamber at the European Photoreactor (EUPHORE) facility, situated in Valencia, Spain. Technical information concerning the installation and its use for VOC oxidation experiments has been previously reported in the literature (Becker, 1996; Volkamer et al., 2001; Wenger et al., 2004). The chambers are hemispheres made of FEP (fluorinated ethylene propylene) foil, with an approximate volume of $200 \mathrm{~m}^{3}$, and are surrounded by a retractable steel housing. The ozonolysis reactions were performed using starting concentrations of around $1.6 \mathrm{ppmv}$ of reactant and ozone. No radical scavenger or seed aerosol was used and the relative humidity was around $6 \%$. The decay of the hydrocarbon was monitored by FTIR spectroscopy and gas chromatography and the formation and evolution of SOA was measured using a scanning mobility particle sizer (TSI 3022A condensation particle counter and TSI 3081 differential mobility analyzer). Samples of SOA were collected onto quartz filter papers when the particle concentration in the chamber had reached a maximum, approximately $4 \mathrm{~h}$ after the start of the reaction. The samples were collected at $81.2 \mathrm{~L} \mathrm{~min}-1$ (at $25^{\circ} \mathrm{C}$ ), for $60 \mathrm{~min}$ and stored in a freezer at $-4^{\circ} \mathrm{C}$ before analysis. Filter samples were extracted into high purity water, filtered and reduced to $1 \mathrm{ml}$ using a vacuum solvent evaporator (Biotage, Sweden). Liquid chromatography-ion trap mass spectrometry was carried out using HCT Plus ion trap mass spectrometer (Bruker Daltonics $\mathrm{GmbH}$, Bremen, Germany) equipped with an Eclipse ODS- $\mathrm{C}_{18}$ column with $5 \mu \mathrm{m}$ particle size (Agilent, $4.6 \mathrm{~mm} \times 150 \mathrm{~mm}$ ). Full details have been published previously (Hamilton et al., 2008).

Experiments to determine the yield of SOA produced from the hydroxyl radical initiated oxidation of cis-3-hexen-1-ol, cis-3-hexenyl acetate and isoprene were performed using nitrous acid (HONO, $100 \mathrm{ppbv})$ as the $\mathrm{OH}$ precursor and a VOC mixing ratio of 500 ppbv. The yield of SOA produced in each experiment was calculated from the ratio of the aerosol mass formed to the amount of hydrocarbon reacted at the point where the maximum particle concentration was observed. The aerosol mass was corrected for wall losses by applying a first order loss rate obtained from the measured decay of the particles at the end of each experiment. The particle mass was calculated from the SMPS measured volume concentration using a density of $1 \mathrm{~g} \mathrm{~cm}^{-3}$. A summary of the initial reaction conditions and yields of SOA obtained in the photooxidation and ozonolysis experiments is provided in Table 1.

\section{Results and discussion}

\subsection{Chemical composition of SOA}

Detailed chemical characterisation of the SOA produced from ozonolysis of the GLVs was performed using electrospray ionisation-liquid chromatography coupled to quadrupole ion trap mass spectrometry $\left(\mathrm{LC}_{\mathrm{MS}}{ }^{n}\right)$. This technique has previously been used to identify polar compounds and oligomers in SOA formed in a variety of systems 


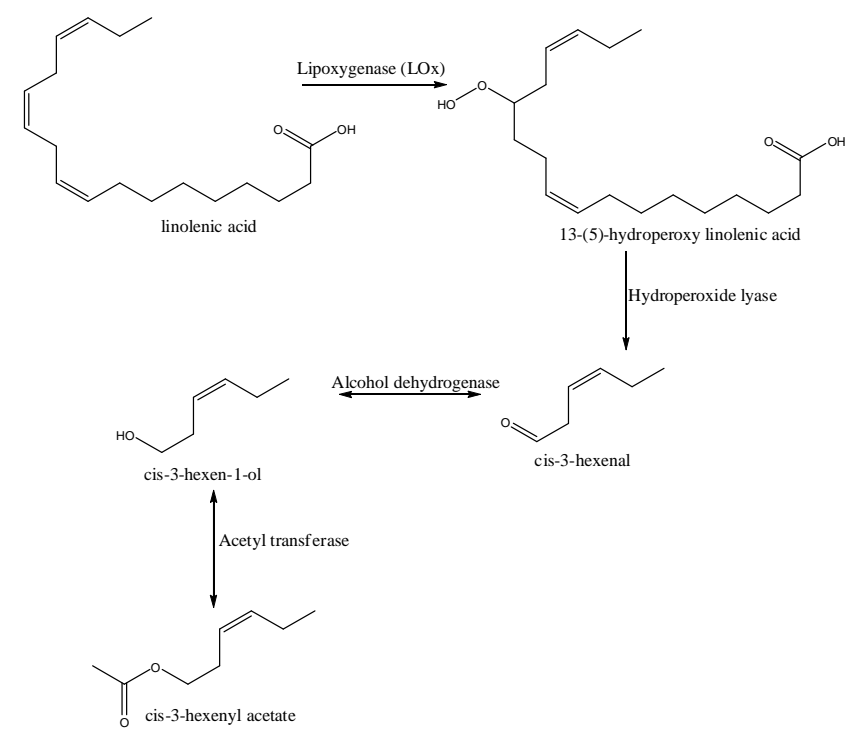

Fig. 1. The formation pathway of green leaf volatiles from linolenic acid in plant cells. Reproduced from Beauchamp et al. (2005).

(Hamilton et al., 2008). In order to improve the sensitivity of the technique and improve structural detail, we introduced a low concentration of $\mathrm{LiBr}$ to act as a cationisation agent, so that all positive ions existed as $[\mathrm{M}+\mathrm{Li}]^{+}$adducts (Hamilton et al., 2008). Extracts were directly injected into the MS without any pre-separation to obtain the mass distribution of the organic species present in the SOA. The mass spectra obtained in positive ionisation mode are shown in Fig. 2 and exhibit significantly different patterns and distributions of product ions, even though the two precursor molecules are structurally related.

The mass spectrum of cis-3-hexenylacetate SOA (Fig. 2, upper panel) was dominated by a small number of compounds separated by 14,16 and $18 \mathrm{Da}$, corresponding to $\left(\mathrm{CH}_{2}\right), \quad(\mathrm{O})$ and $\left(\mathrm{H}_{2} \mathrm{O}\right)$ respectively. The major small molecules identified were 3acetoxypropanal $\left([\mathrm{M}+\mathrm{Li}]^{+}=123 \mathrm{Da}\right), 3$-acetoxypropanoic acid $\left([\mathrm{M}+\mathrm{Li}]^{+}=139 \mathrm{Da}\right)$ and 3 -acetoxypropane peroxoic acid $\left([\mathrm{M}+\mathrm{Li}]^{+}=155 \mathrm{Da}\right)$. A range of higher molecular weight species were identified as oligomers containing ester and ether linkages, produced from chemical reactions in the particle-phase (Hamilton et al., 2008). Collision induced fragmentation of the majority of the oligomers resulted in the loss of 60,116 and $132 \mathrm{Da}$, corresponding to the loss of the acetate functionality (as acetic acid) and two of the major small molecules, 3-acetoxy propanal (116 Da) and 3 -acetoxy-propanoic acid (132 Da) as shown in the constant neutral loss chromatograms in Fig. 3. In nearly all cases, the oligomers lost a fragment related to a terminal acetate group. This indicates that the acetate functionality does not participate in heterogeneous reactions, effectively blocking further oligomeric growth. The most abundant oligomers in

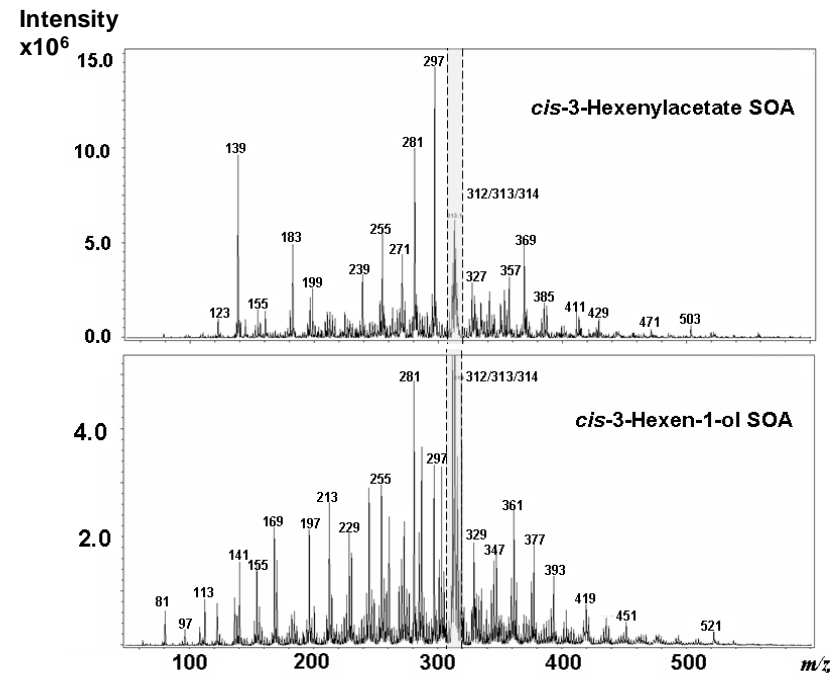

Fig. 2. Average mass spectrum (in positive ionisation mode) of the water extract of secondary organic aerosol formed during the ozonolysis of cis-3-hexenylacetate and cis-3-hexen-1-ol. All species are displayed as their $[\mathrm{M}+\mathrm{Li}]^{+}$adducts (e.g. the peak at $113 \mathrm{Da}$ is due to a compound with a molecular mass of 106). The features at $312-314 \mathrm{Da}$ in both spectra were also present in blank filter samples and are probably due to low-level contaminants in the chamber.

cis-3-hexenylacetate SOA corresponded to dimer and trimer structures. We propose that the lack of higher oligomers is a result of the low reactivity of the acetate group, i.e. no further growth may occur when a species has an acetate functional group at both ends.

The cis-3-hexen-1-ol SOA (Fig. 2, lower panel) produced a very different molecular mass distribution, with groups of peaks, 6 to $8 \mathrm{Da}$ wide and separated by 14 or $16 \mathrm{Da}$, appearing throughout the range ca. 80-500, with a maximum abundance around $280 \mathrm{Da}$. This type of molecular mass distribution is similar to that reported for SOA produced from the photooxidation of 1,3,5-trimethylbenzene (Kalberer et al., 2004) and indicates that significant amounts of oligomers are present. It is estimated that over $90 \%$ of the particle mass identified here consists of oligomers including ester and ether type linkages, produced from the heterogeneous reaction of oxidation products. Fragmentation of SOA products isolated using LC, resulted in a larger range of neutral loss fragments rather than the very dominant losses shown for cis-3-hexenylacetate above. The most common losses were 18,74 and $90 \mathrm{Da}$, with the last two also commonly seen as their $[\mathrm{M}+\mathrm{Li}]^{+}$product ions, 81 and $97 \mathrm{Da}$. Further fragmentation indicated these two oligomer fragments corresponded to 3-hydroxy-propanal (3-HPA) and 3-hydroxypropanoic acid (3-HPAcid). 3-HPA, along with propanal, has previously been identified as a major gas phase product from cis-3-hexen-1-ol ozonolysis with a formation yield of approximately 33\% (Aschmann et al., 1997). In the presence 
Table 1. Details of the simulation chamber experiments.

\begin{tabular}{lcccccc}
\hline Experiment & $\begin{array}{c}{\left[\mathrm{O}_{3}\right]} \\
(\mathrm{ppbv})\end{array}$ & $\begin{array}{c}{[\mathrm{HONO}]_{0}} \\
(\mathrm{ppbv})\end{array}$ & $\begin{array}{c}{[\mathrm{HC}]_{0}} \\
(\mathrm{ppbV})\end{array}$ & $\begin{array}{c}\Delta[\mathrm{HC}]^{\mathrm{a}} \\
(\mathrm{ppbv})\end{array}$ & $\begin{array}{c}\text { Aerosol Mass }^{\mathrm{b}} \\
\left(\mu \mathrm{g} \mathrm{m}^{-3}\right)\end{array}$ & $\begin{array}{c}\text { Aerosol Yield }^{c} \\
(\%)\end{array}$ \\
\hline $\begin{array}{l}\text { cis-3-hexenylacetate ozonolysis } \\
\text { cis-3-hexen-1-ol ozonolysis }\end{array}$ & 1460 & & 1602 & 1335 & 800 & 8.5 \\
cis-3-hexenylacetate photooxidation & 1600 & & 1580 & 1404 & 854 & 9.6 \\
cis-3-hexen-1-ol photooxidation & & 105 & 498 & 489 & 9.7 & 0.9 \\
isoprene photooxidation & & 103 & 449 & 434 & 43.2 & 3.1 \\
\end{tabular}

a Amount of parent hydrocarbon (HC) reacted, corrected for dilution.

${ }^{\mathrm{b}}$ Determined at the time of measured maximum particle volume concentration, corrected for wall loss, assuming a density of $1.0 \mathrm{~g} \mathrm{~cm}{ }^{-3}$.

${ }^{\mathrm{c}}$ Calculated from aerosol mass/ $\Delta[\mathrm{HC}]$.

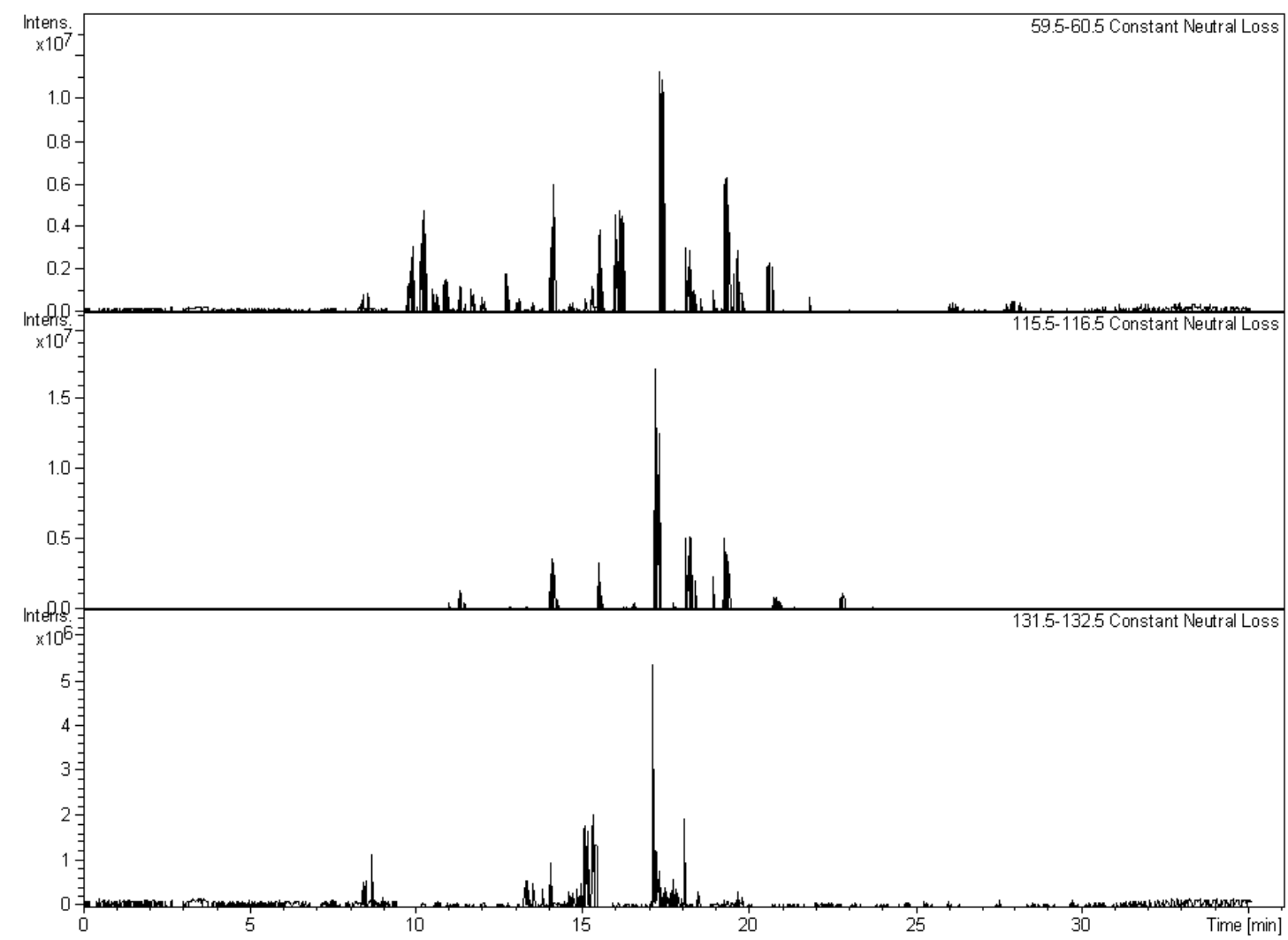

Fig. 3. Constant Neutral Loss Chromatogram of the water extract of cis-3-hexenylacetate SOA. Peaks correspond to compounds that lost a specified mass as a neutral molecule during fragmentation. Upper: Loss of $60 \mathrm{Da}$ (acetic acid). Middle: Loss of 116 Da (3-acetoxy propanal). Lower: Loss of $132 \mathrm{Da}$ (3-acetoxy-propanoic acid).

of water, 3-HPA is known to undergo reversible hydration and dimerization, similar to that seen with glyoxal (Hastings et al., 2005), to form higher molecular weight species as seen in Fig. 4. Ions matching the dimer, trimer and tetramer masses $\left([\mathrm{M}+\mathrm{Li}]^{+}=155,229,303 \mathrm{Da}\right)$ were found in the spectrum and fragmentation yields 3-HPA and 3-HPAcid product ions. These subsequently were separated chromatographically and are therefore not artefacts of the electrospray ionisation. Aschmann et al. (1997) also detected a gas phase product that they tentatively identified as the 3-HPA dimer, which is consistent with the results presented here. Hydrated 3-HPA can also react with other aldehydes, in this case propanal, to form a cyclic ether, $[\mathrm{M}+\mathrm{Li}]^{+}=139 \mathrm{Da}$, shown in Fig. 4.

3-HPAcid can form linear and cyclic polyesters (via self reaction or with other oxidised products), both of which 

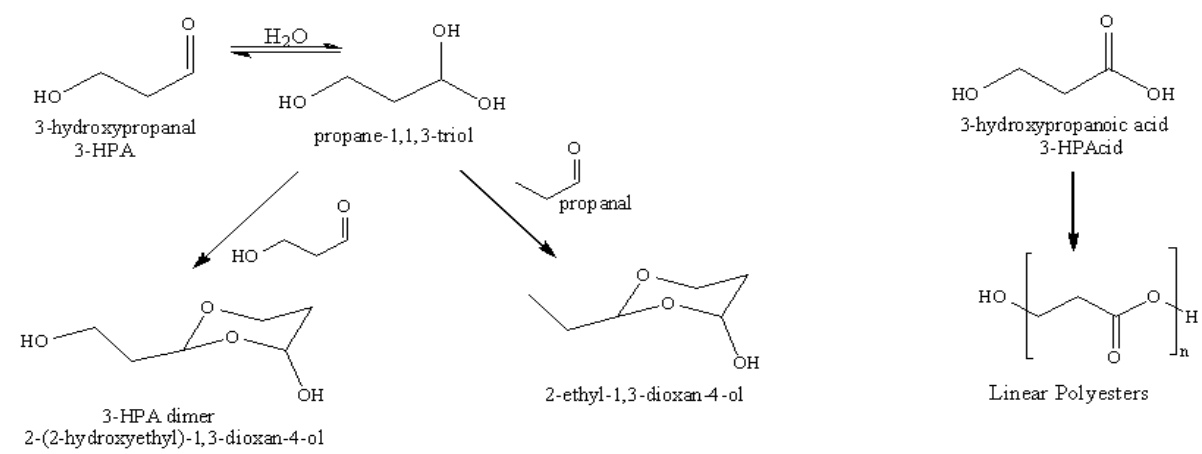

Fig. 4. Proposed pathways for formation of oligomers from reactions of the atmospheric oxidation products of $c i s-3$-hexen-1-ol.

Table 2. Oligomers identified in SOA produced from the atmospheric oxidation of cis-3-hexen-1-ol. $^{\text {a }}$ Tentative identification.

\begin{tabular}{|c|c|c|c|c|}
\hline Name & Structure & $\begin{array}{c}\text { Name in } \\
\text { paper }\end{array}$ & $\begin{array}{c}\mathrm{MW} \\
\left(\mathrm{g} \mathrm{mol}^{-1}\right)\end{array}$ & {$[\mathrm{M}+\mathrm{Li}]^{+}$} \\
\hline $\begin{array}{l}\text { 2-ethyl-1,3- } \\
\text { dioxan-4-ol }\end{array}$ & & $\begin{array}{c}\text { HPA+ } \\
\text { propanal }\end{array}$ & 132 & 139 \\
\hline $\begin{array}{l}\text { 3-(2-hydroxy } \\
\text { ethoxy) propanoic } \\
\text { acid }\end{array}$ & но & & 134 & 141 \\
\hline $\begin{array}{c}2-(2- \\
\text { hydroxyethyl) } \\
\text { 1,3-dioxan-4-ol }\end{array}$ & $\mathrm{HO}^{-}$ & $\begin{array}{l}\text { HPA } \\
\text { dimer }\end{array}$ & 148 & 155 \\
\hline $\begin{array}{l}\text { 3-(3-hydroxy } \\
\text { propanoyloxy) } \\
\text { propanoic acid }\end{array}$ & & $\begin{array}{l}\text { HPAcid } \\
\text { dimer }\end{array}$ & 162 & 169 \\
\hline $\begin{array}{c}\text { 3-(3-(2- } \\
\text { hydroxyethoxy) } \\
\text { propanoyloxy) } \\
\text { propanoic acid }\end{array}$ & & & 206 & 213 \\
\hline $\begin{array}{l}\text { 3-(3-(2-hydroxy } \\
\text { ethoxy)-3- } \\
\text { oxopropanoyloxy) } \\
\text { propanoic acid }\end{array}$ & & & 220 & 227 \\
\hline $\begin{array}{l}\text { 3-(3-hydroxy-3- } \\
\text { (2-hydroxyethoxy) } \\
\text { propanoyloxy } \\
\text { propanoic acid } \\
\end{array}$ & & & 222 & 229 \\
\hline $\begin{array}{c}\text { 1-(2-(4-hydroxyl- } \\
\text { 1,3-dioxan-2-yl)- } \\
\text { ethoxy)-propane- } \\
\text { 1,3-diol }{ }^{\mathrm{a}}\end{array}$ & & $\begin{array}{l}\text { HPA } \\
\text { trimer }\end{array}$ & 222 & 229 \\
\hline $\begin{array}{c}\text { 1,3-dihydrox-3-(2- } \\
\text { hydroxyethoxy) } \\
\text { propyl-3-hydroxy } \\
\text { propanoate }\end{array}$ & но- & & 224 & 231 \\
\hline \multirow[t]{2}{*}{$\begin{array}{l}\text { 3-(3-(3-hydroxy } \\
\text { propanoyloxy) } \\
\text { propanoyloxy } \\
\text { propanoic acid }\end{array}$} & $\overbrace{\mathrm{O}}^{\mathrm{HO}} \mathrm{C}_{3}^{\mathrm{O}}$ & $\begin{array}{l}\text { HPAcid } \\
\text { trimer }\end{array}$ & 234 & 241 \\
\hline & Insufficient detail in MS2 spectra for identification & $\begin{array}{c}\text { HPA } \\
\text { tetramer }\end{array}$ & 296 & 303 \\
\hline $\begin{array}{c}\text { 3-(3-(3-(3- } \\
\text { hydroxy } \\
\text { propanoyloxy) } \\
\text { propanoyloxy) } \\
\text { propanoyloxy } \\
\text { propanoic acid }\end{array}$ & $\overbrace{\mathrm{O}}^{\mathrm{HO}} \overbrace{4}^{\mathrm{O}}$ & $\begin{array}{l}\text { HPAcid } \\
\text { tetramer }\end{array}$ & 306 & 313 \\
\hline
\end{tabular}


would also result in the loss of a 81 or $97 \mathrm{Da}[\mathrm{M}+\mathrm{Li}]^{+}$fragment. There is no evidence for the formation of the cyclic esters (from self reaction), but there are peaks that correspond to the $\mathrm{n}=2,3,4$ and 5 linear esters $\left([\mathrm{M}+\mathrm{Li}]^{+}=169\right.$, 241, 313, $385 \mathrm{Da}$ ) shown in Fig. 4. High resolution mass spectrometry would be required to elucidate larger structures due to the high number of isobaric ions and inconclusive fragmentation patterns. However, the major monomer units lost during fragmentation of oligomers were 3-HPA, 3-HPAcid, malonic acid (104 Da), acrylic acid (72 Da), 1,3propanediol $(76 \mathrm{Da})$ and 1,2-ethanediol $(62 \mathrm{Da})$. The complete list of oligomeric structures identified in cis-hexen-1-ol SOA is shown in Table 2.

Thus it appears that the high reactivity of the first generation oxidation product, 3-HPA, may be responsible for the very high relative proportion of oligomers present in cis3-hexen-1-ol SOA. 3-HPA has a calculated vapour pressure of 9.5 Torr at $298 \mathrm{~K}$ (Jenkin, 2004) and significant amounts would not be detected in SOA if absorptive partitioning was the sole means of transfer to the particle phase. As a result it seems most likely that uptake of 3-HPA is followed by the particle phase reactions shown in Fig. 4 which result in the formation of products with considerably lower volatility that would therefore remain in the particle phase. The super cooled liquid vapour pressures of the 3-HPA dimer and trimer are calculated to be $2 \times 10^{-3}$ Torr and $1.9 \times 10^{-7}$ Torr respectively (Jenkin, 2004). This corresponds to a factor of $10^{8}$ decrease in vapour pressure between the monomer and trimer products.

The range and complexity of organic emissions to the atmosphere is such that it is unrealistic to expect unique simulation chamber experiments to determine SOA yields for each individual compound. However the degradation schemes for many organic compounds yield common intermediates, and the reactivity of such intermediates may be assessed from literature - the key intermediate in this work 3-HPA, is predicted as a major oxidation product from other precursor compounds and its high reactivity has already been documented in other fields (Vollenweider and Lacroix, 2004). Furthermore, 3-HPAcid has been proposed as a key monomer in oligomers formed by in-cloud processing of methylglyoxal, an oxidation product of both biogenic and aromatic VOCs (Altieri et al., 2008). The experiments presented here were carried out at low relative humidity $(6 \%)$ and thus unlikely to be occurring in an aqueous phase. If the 3-HPA oligomers are the nucleating species it is likely that the hydration step is a gas phase process.

An organic mechanistic approach to SOA prediction may therefore be possible with the reactivity of intermediate oxidation products being incorporated in addition to commonly used parameters such as vapour pressure and activity coefficient. By understanding which functional groups (rather than compound-by-compound) either promote or block oligomerisation, there is scope to improve SOA formation within models which may use simplified or bulked treatments of more complex explicit chemical mechanisms (Johnson et al., 2005).

\subsection{GLVs as a global source of SOA}

Very little is known about the atmospheric concentrations and global fluxes of the GLVs. An extensive review of previous literature yields very few ambient measurements in remote environments. In one study, proton transfer reaction - mass spectrometry (PTR-MS) was used to measure VOC concentrations above the canopy of the tropical rainforest in Surinam (Williams et al., 2001). A maximum mixing ratio for cis-3-hexen-1-ol of 732 pptv was determined, which was around a third of the maximum value recorded for isoprene (1.7 ppbv). Other studies have shown short, high concentration pulses of GLVs under a range of plant stress factors. It is clear that the plant processes leading to emissions of GLV compounds are well documented but the atmospheric impacts of these emissions are not, probably due to the transient nature and variability of stress induced emissions. Annual global emissions of cis-3-hexen-1-ol and cis3-hexenyl acetate are both estimated to be in the region of 10 to $50 \mathrm{TgC} \mathrm{yr}^{-1}$, which is in the same mass range as $\beta$-pinene, ethanol and acetone (Wiedinmyer et al., 2004). Isoprene is estimated to be in the region of $250-750 \mathrm{TgC} \mathrm{yr}^{-1}$.

Current bottom up estimates of BSOA production rates, based on yields obtained in simulation chamber studies are in the region of $12-70 \mathrm{TgC} \mathrm{yr}^{-1}$ (Kanakidou et al., 2005). Claeys et al. (2004) estimated the SOA mass yield from isoprene to be $0.4 \%$ based on ambient measurements of isoprene oxidation products, including methyl-tetrols. However, this is based on the identification of a small subset of isoprene products in ambient SOA and recent modelling and chamber studies indicate this is likely to be an underestimate (Henze and Seinfeld, 2006; Kroll et al., 2006), predicting around a $3 \%$ yield or $13 \mathrm{TgC} \mathrm{yr}^{-1}$. Since such measurements do not currently exist for the oxidation products of GLV compounds, we carried out a series of simulation chamber experiments to compare the yields of SOA generated from the atmospheric oxidation of isoprene, cis-3-hexen-1-ol and cis-3hexenyl acetate under identical conditions. Because ozonolysis is only believed to be a minor contributor to SOA formation from isoprene (Kleindienst et al., 2007), this second set of experiments were performed using hydroxyl radicals $(\mathrm{OH})$ to initiate the oxidation process. The $\mathrm{OH}$-initiated oxidation of the GLVs is known to produce the same major reaction products as ozonolysis, i.e. 3-HPA and propanal, (Reisen et al., 2003) and the subsequent chemistry related to SOA formation is expected to be similar. The reaction mixtures containing the VOC (ca. 500 ppbv) and nitrous acid (HONO, $100 \mathrm{ppbv}$ ) as $\mathrm{OH}$ precursor were exposed to sunlight and the formation and evolution of SOA was monitored as shown in Fig. 5. The peak in SOA in Fig. 5a and c early in the experiment is due to inaccurate noise removal of large particles in the SMPS and should be ignored. 
The following aerosol mass yields were obtained; cis-3hexen-1-ol (3.1\%), cis-3-hexenyl acetate $(0.93 \%)$ and isoprene $(1.2 \%)$. Due to the slower reaction rate, the cis-3hexenyl acetate SOA is just starting to plateau at the end of the experiment and this final value has been used for yield calculations. Assuming that these SOA yields can be scaled according to the value typically used for isoprene (3\%), the relative yields of SOA produced from cis-3-hexen-1-ol and cis-3-hexenyl acetate in the atmosphere are $7.75 \%$ and $2.25 \%$ respectively. This leads to an estimated global SOA source of $1-5 \mathrm{TgC} \mathrm{yr}^{-1}$ from the $\mathrm{OH}$-initiated oxidation of these two GLVs, up to a third of that from isoprene. The SOA yields from ozonolysis (at initial concentrations of $1600 \mathrm{ppbv}$ ) were 9.5\% for cis-3-hexen-1-ol and $8.6 \%$ for cis-3-hexenyl acetate, indicating that ozonolysis is likely to be an additional SOA production route for these GLVs.

A recent estimate of global SOA production based on VOC fluxes by Goldstein and Galbally indicated that there may be significant missing SOA precursors that are currently unknown (Goldstein and Galbally, 2007). The results obtained in this study indicate that GLVs may be an important part of this unidentified global source of SOA, which have been overlooked as a consequence of their volatile first generation oxidation products. Here only 2 compounds have been considered, but there are a number of other GLV species emitted into the atmosphere (e.g. trans-3-hexenal, cis-2-hexenal, cis-2-hexenol) indicating that the SOA potential of green leaf volatiles may be considerably higher than estimated here. Clearly, considerable further work on emission fluxes, simulation chamber studies, field measurements and modelling is required to fully evaluate the importance of GLVs to the SOA budget. Future scenarios may also be considered, where higher emissions of GLVs could arise from plant stress induced by extreme temperatures or high ozone concentrations, or from the use of plants for biofuels (GLV emissions are major emission from oil seed rape).

\section{Conclusions}

Molecular characterization of the SOA produced from the ozonolysis of cis-3-hexen-1-ol and cis-3-hexenylacetate indicates that the formation and composition of organic aerosols from these GLVs is strongly influenced by the reactivity of their first generation atmospheric oxidation products. Evidence is provided to indicate that 3-hydroxypropanal, the primary oxidation product of cis-3-hexen-1-ol, can hydrate and undergo further reactions with other aldehydes resulting in SOA dominated by higher molecular weight oligomers. In contrast, there are considerably less higher molecular weight species present in the SOA produced from ozonolysis of cis3-hexenylacetate. This is attributed to the acetate functionality, which inhibits oligomer formation in the particle phase. The SOA yields obtained from the photooxidation of cis-3hexen-1-ol and cis-3-hexenylacetate are compared to those

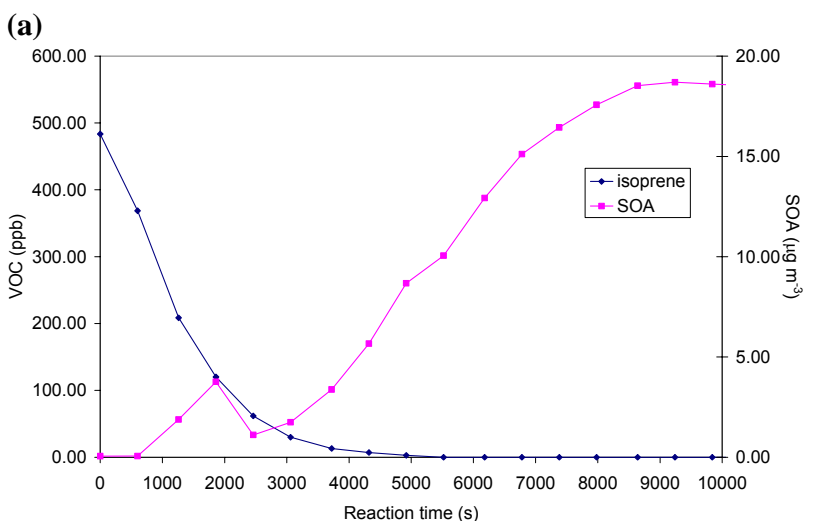

(b)

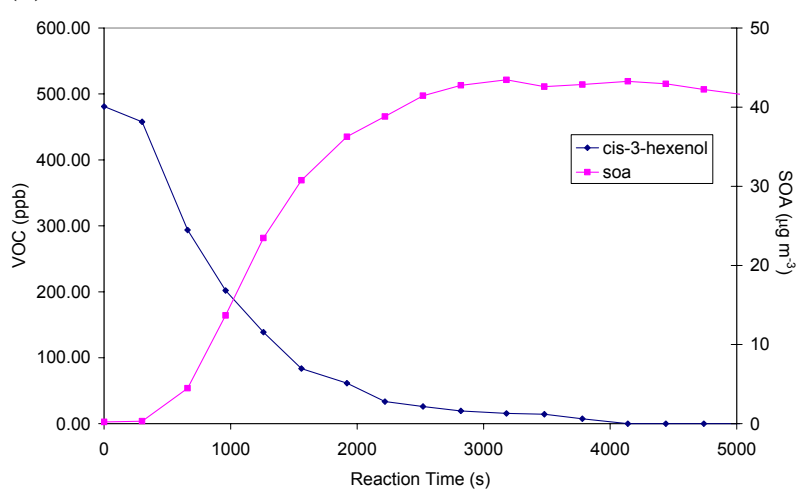

(c)

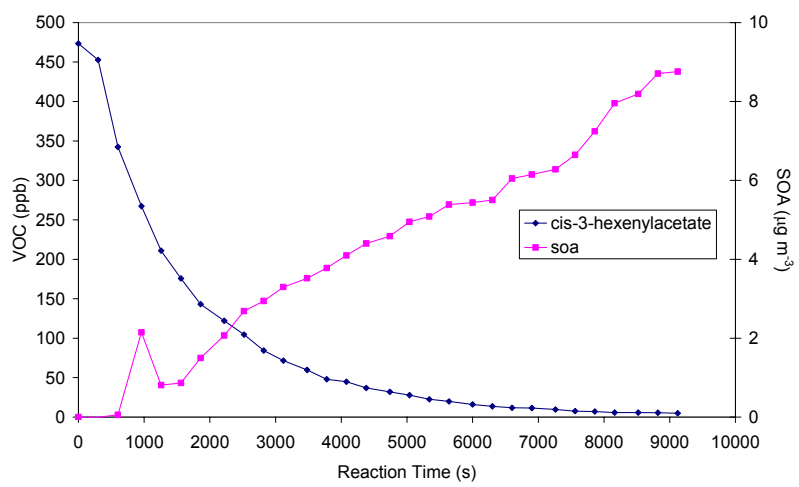

Fig. 5. SOA formation during the photooxidation experiments. (a) Isoprene. (b) cis-3-hexen-1-ol. (c) cis-3-hexenylacetate.

obtained from isoprene. The results are used, in conjunction with estimated emission fluxes, to show that GLVs may be a substantial unidentified global source of SOA, contributing $1-5 \mathrm{TgC} \mathrm{yr}^{-1}$, equivalent to around a third of that predicted from isoprene. 
Acknowledgements. This work was part funded by the Natural Environment Research Council APPRAISE program and EROS project (R8/H10/34, NE/E00685X/1), the European Commission (project EUROCHAMP, contract number RII3-CT-2004-505968) and the European Science Foundation (INTROP programme). We would like to thank the Generalitat Valenciana and the GRACCIE CBS2007-00067 project of the CONSOLIDER-INGENIO 2010 program for supporting this study. In addition, we thank Mila Ródenas, Mónica Vázquez and Maria Marqués for their work on these experiments.

\section{Edited by: V. Faye McNeill}

\section{References}

Altieri, K. E., Seitzinger, S. P., Carlton, A. G., Turpin, B. J., Klein, G. C., and Marshall, A. G.: Oligomers formed through in-cloud methylglyoxal reactions: Chemical composition, properties, and mechanisms investigated by ultra-high resolution FT-ICR mass spectrometry, Atmos. Environ., 42, 1476-1490, 2008.

Arey, J., Winer, A. M., Atkinson, R., Aschmann, S. M., Long, W. D., and Morrison, C. L.: The Emission of (Z)-3-hexen-1-ol, (Z)3-hexenylacetate and other oxygenated hydrocarbons from agricultural plant species, Atmos. Environ., 25, 1063-1075, 1991.

Aschmann, S. M., Shu, Y. H., Arey, J., and Atkinson, R.: Products of the gas-phase reactions of cis-3-hexen-1-ol with $\mathrm{OH}$ radicals and $\mathrm{O}_{3}$, Atmos. Environ., 31, 3551-3560, 1997.

Atkinson, R. and Arey, J.: Gas-phase tropospheric chemistry of biogenic volatile organic compounds: a review, Atmos. Environ., 37, S197-S219, 2003.

Atkinson, R., Arey, J., Aschmann, S. M., Corchnoy, S. B., and Shu, Y. H.: Rate Constants for the gas-phase reactions of cis-3-Hexen1-ol, cis-3-hexenylacetate, trans-2-hexenal, and linalool with $\mathrm{OH}$ and $\mathrm{NO}_{3}$ radicals and $\mathrm{O}_{3}$ at $296 \pm 2 \mathrm{~K}$ and $\mathrm{OH}$ radical formation yields from the $\mathrm{O}_{3}$ Reactions, Int. J. Chem. Kinet., 27, 941-955, 1995.

Beauchamp, J., Wisthaler, A., Hansel, A., Kleist, E., Miebach, M., Niinemets, U., Schurr, U., and Wildt, J.: Ozone induced emissions of biogenic VOC from tobacco: relationships between ozone uptake and emission of LOX products, Plant Cell Environ., 28, 1334-1343, 2005.

Becker, K. H.: The European Photoreactor EUPHORE, Final Report of the EU project, EV5V-CT92-00591996.

Bonn, B. and Moortgat, G. K.: Sesquiterpene ozonolysis: Origin of atmospheric new particle formation from biogenic hydrocarbons, Geophys. Res. Lett., 30, 1585-1588, 2003.

Claeys, M., Graham, B., Vas, G., Wang, W., Vermeylen, R., Pashynska, V., Cafmeyer, J., Guyon, P., Andreae, M. O., Artaxo, P., and Maenhaut, W.: Formation of secondary organic aerosols through photooxidation of isoprene, Science, 303, 1173-1176, 2004.

Fuentes, J. D., Lerdau, M., Atkinson, R., Baldocchi, D., Bottenheim, J. W., Ciccioli, P., Lamb, B., Geron, C., Gu, L., Guenther, A., Sharkey, T. D., and Stockwell, W.: Biogenic hydrocarbons in the atmospheric boundary layer: A review, B. Am. Meteorol. Soc., 81, 1537-1575, 2000.

Fuzzi, S., Andreae, M. O., Huebert, B. J., Kulmala, M., Bond, T. C., Boy, M., Doherty, S. J., Guenther, A., Kanakidou, M., Kawamura, K., Kerminen, V.-M., Lohmann, U., Russell, L. M., and Pöschl, U.: Critical assessment of the current state of scientific knowledge, terminology, and research needs concerning the role of organic aerosols in the atmosphere, climate, and global change, Atmos. Chem. Phys., 6, 2017-2038, 2006, http://www.atmos-chem-phys.net/6/2017/2006/.

Goldstein, A. H. and Galbally, I. E.: Known and unexplored organic constituents in the earth's atmosphere, Environ. Sci. Technol., 41, 1514-1521, 2007.

Guenther, A., Hewitt, C. N., Erickson, D., Fall, R., Geron, C., Graedel, T., Harley, P., Klinger, L., Lerdau, M., Mckay, W. A., Pierce, T., Scholes, B., Steinbrecher, R., Tallamraju, R., Taylor, J., and Zimmerman, P.: A global model of natural volatile organic compound emissions, J. Geophys. Res., 100, 8873-8892, 1995.

Hamilton, J. F., Lewis, A. C., Carey, T. J., and Wenger, J. C.: Characterization of polar compounds and oligomers in secondary organic aerosol using liquid chromatography coupled to mass spectrometry, Anal. Chem., 80, 474-480, 2008.

Hastings, W. P., Koehler, C. A., Bailey, E. L., and De Haan, D. O.: Secondary organic aerosol formation by glyoxal hydration and oligomer formation: Humidity effects and equilibrium shifts during analysis, Environ. Sci. Technol., 39, 8728-8735, 2005.

Henze, D. K. and Seinfeld, J. H.: Global secondary organic aerosol from isoprene oxidation, Geophys. Res. Lett., 33, L09812, doi:10.1029/2006GL025976, 2006.

Hoffmann, T. and Warnke, J.: Organic Aerosols, in: Volatile Organic Compounds in the Atmosphere, edited by: Koppmann, R., Blackwell Publishing Ltd., Oxford, UK, 342-387, 2007.

Holzinger, R., Lee, A., Paw, K. T., and Goldstein, U. A. H.: Observations of oxidation products above a forest imply biogenic emissions of very reactive compounds, Atmos. Chem. Phys., 5, 67-75, 2005, http://www.atmos-chem-phys.net/5/67/2005/.

Intergovernmental Panel on Climate Change (IPCC): Climate Change 2007: The Physical Science Basis, Cambridge University Press, UK, 2007.

Jenkin, M. E.: Modelling the formation and composition of secondary organic aerosol from $\alpha$ - and $\beta$-pinene ozonolysis using MCM v3, Atmos. Chem. Phys., 4, 1741-1757, 2004, http://www.atmos-chem-phys.net/4/1741/2004/.

Johnson, D., Jenkin, M. E., Wirtz, K., and Martin-Reviejo, M.: Simulating the formation of secondary organic aerosol from the photooxidation of aromatic hydrocarbons, Environ. Chem., 2, 3548, 2005.

Joutsensaari, J., Loivamäki, M., Vuorinen, T., Miettinen, P., Nerg, A.-M., Holopainen, J. K., and Laaksonen, A.: Nanoparticle formation by ozonolysis of inducible plant volatiles, Atmos. Chem. Phys., 5, 1489-1495, 2005,

http://www.atmos-chem-phys.net/5/1489/2005/.

Kalberer, M., Paulsen, D., Sax, M., Steinbacher, M., Dommen, J., Prevot, A. S. H., Fisseha, R., Weingartner, E., Frankevich, V., Zenobi, R., and Baltensperger, U.: Identification of polymers as major components of atmospheric organic aerosols, Science, 303, 1659-1662, 2004.

Kanakidou, M., Seinfeld, J. H., Pandis, S. N., Barnes, I., Dentener, F. J., Facchini, M. C., Van Dingenen, R., Ervens, B., Nenes, A., Nielsen, C. J., Swietlicki, E., Putaud, J. P., Balkanski, Y., Fuzzi, S., Horth, J., Moortgat, G. K., Winterhalter, R., Myhre, C. E. L., Tsigaridis, K., Vignati, E., Stephanou, E. G., and Wilson, J.: 
Organic aerosol and global climate modelling: a review, Atmos. Chem. Phys., 5, 1053-1123, 2005,

http://www.atmos-chem-phys.net/5/1053/2005/.

Karl, T., Fall, R., Crutzen, P. J., Jordan, A., and Lindinger, W.: High concentrations of reactive biogenic VOCs at a high altitude site in late autumn, Geophys. Res. Lett., 28, 507-510, 2001.

Kesselmeier, J. and Staudt, M.: Biogenic volatile organic compounds (VOC): An overview on emission, physiology and ecology, J. Atmos. Chem, 33, 23-88, 1999.

Kirstine, W. V. and Galbally, I. E.: A simple model for estimating emissions of volatile organic compounds from grass and cut grass in urban airsheds and its application to two Australian cities, J. Air. Waste. Manage., 54, 1299-1311, 2004.

Kleindienst, T. E., Lewandowski, M., Offenberg, J. H., Jaoui, M., and Edney, E. O.: Ozone-isoprene reaction: Re-examination of the formation of secondary organic aerosol, Geophys. Res. Lett., 34, L01805, doi:10.1029/2006GL027485, 2007.

Konig, G., Brunda, M., Puxbaum, H., Hewitt, C. N., Duckham, S. C., and Rudolph, J.: Relative contribution of oxygenated hydrocarbons to the total biogenic VOC emissions of selected midEuropean agricultural and natural plant species, Atmos. Environ., 29, 861-874, 1995.

Kroll, J. H., Ng, N. L., Murphy, S. M., Flagan, R. C., and Seinfeld, J. H.: Secondary organic aerosol formation from isoprene photooxidation, Environ. Sci. Technol., 40, 1869-1877, 2006.

Larsen, B. R., Di Bella, D., Glasius, M., Winterhalter, R., Jensen, N. R., and Hjorth, J.: Gas-phase OH oxidation of monoterpenes: Gaseous and particulate products, J. Atmos. Chem., 38, 231-276, 2001.

Lee, A., Goldstein, A. H., Kroll, J. H., Ng, N. L., Varutbangkul, V., Flagan, R. C., and Seinfeld, J. H.: Gas-phase products and secondary aerosol yields from the photooxidation of 16 different terpenes, J. Geophys. Res., 111, D17305, doi:10.1029/2006JD007050, 2006.

Olofsson, M., Ek-Olausson, B., Ljungstrom, E., and Langer, S.: Flux of organic compounds from grass measured by relaxed eddy accumulation technique, J. Environ. Monitor., 5, 963-970, 2003.
Ortega, J. and Helmig, D.: Approaches for quantifying reactive and low-volatility biogenic organic compound emissions by vegetation enclosure techniques - Part A, Chemosphere, 72, 343-364, 2008.

Penuelas, J. and Llusia, J.: Seasonal patterns of non-terpenoid C6C10 VOC emission from seven Mediterranean woody species, Chemosphere, 45, 237-244, 2001.

Reisen, F., Aschmann, S. M., Atkinson, R., and Arey, J.: Hydroxyaldehyde products from hydroxyl radical reactions of Z-3hexen-1-ol and 2-methyl-3-buten-2-ol quantified by SPME and API-MS, Environ. Sci. Technol., 37, 4664-4671, 2003.

Volkamer, R., Platt, U., and Wirtz, K.: Primary and secondary glyoxal formation from aromatics: Experimental evidence for the bicycloalkyl-radical pathway from benzene, toluene, and pxylene, J. Phys. Chem. A., 105, 7865-7874, 2001.

Vollenweider, S. and Lacroix, C.: 3-Hydroxypropionaldehyde: applications and perspectives of biotechnological production, Appl. Microbiol. Biot., 64, 16-27, 2004.

Wenger, J. C., Le Calve, S., Sidebottom, H. W., Wirtz, K., Reviejo, M. M., and Franklin, J. A.: Photolysis of chloral under atmospheric conditions, Environ. Sci. Technol., 38, 831-837, 2004.

Wiedinmyer, C., Guenther, A., Harley, P., Hewitt, N., Geron, C., Artaxo, P., Steinbrecher, R., and Rasmussen, R.: Global organic emissions from vegetation, chapter in: Emissions of Atmospheric Trace Compounds, edited by: Granier, C., Artaxo, P., and Reeves, C.-E, Kluwer Academic Publishers, Dordrecht, The Netherlands, pp. $115-170,2004$.

Williams, J., Pöschl, U., Crutzen, P. J., Hansel, A., Holzinger, R., Warneke, C., Lindinger, W., and Lelieveld, J.: An atmospheric chemistry interpretation of mass scans obtained from a proton transfer mass spectrometer flown over the tropical rainforest of Surinam, J. Atmos. Chem, 38, 133-166, 2001.

Winer, A. M., Arey, J., Atkinson, R., Aschmann, S. M., Long, W. D., Morrison, C. L., and Olszyk, D. M.: Emission rates of organics from vegetation in California central valley, Atmos. Environ. A, 26, 2647-2659, 1992. 